Open Access

\title{
Fever phobia: a comparison survey between caregivers in the inpatient ward and caregivers at the outpatient department in a children's hospital in China
}

\author{
Lili Dong ${ }^{1,2}$, Jiahui Jin ${ }^{1}$, Yili Lu', Lili Jiang ${ }^{1}$ and Xiaoou Shan ${ }^{1 *}$
}

\begin{abstract}
Background: Fever in children is one of the most common clinical symptoms and a chief complaint and a main reason that caregivers took the children to the outpatient service or admitted to hospital. Studies have found that the majority of parents surveyed at a hospital pediatric clinic held unrealistic and unwarranted concerns about fevers, first termed as 'fever phobia' by Schmitt in 1980. In the present study, we explore whether 'fever phobia' exists in Chinese caregivers and investigate whether such phobia is alleviated when admitted to hospital after propaganda of fever related knowledge by doctors and nurses.
\end{abstract}

Methods: A questionnaire was distributed to caregivers of children who visited the pediatric outpatient department and those with caregivers in the wards between June 2012 and Feb 2013 in Wenzhou, China.

Results: Data were obtained from 621 caregivers, 305(49 \%) from the OPD and 316(51\%) from the ward. Most caregivers of the two groups (OPD vs. ward group, 75.1 vs. $74.4 \%$ ) believed fever could cause brain damage. $77.7 \%$ (76.0 vs. $81.3 \%$ ) caregivers were very worried when their children had fever and $12.8 \%$ (14.1 vs. $11.4 \%)$ caregivers would check the temperature within $30 \mathrm{~min}$. Moreover, $68.0 \%$ (63.0 vs. $72.8 \%, P<0.05)$ caregivers would give their children antipyretics during sleep and $39.9 \%$ (40.3 vs. $39.6 \%$ ) would administrate antipyretics when temperature was above $38{ }^{\circ} \mathrm{C}$. After admitted to hospital, $83.9 \%$ caregivers stated to have received education about fever and $96.5 \%$ felt relieved. Less caregivers (ward group vs. OPD, 42.4 vs. $46.9 \%, P<0.05$ ) from ward group would give antipyretics with a temperature under $38.5^{\circ} \mathrm{C}$ and less $(0.6$ vs. $4.9 \%, P<0.05)$ preferred cold sponging as physical cooling method compared to the OPD caregivers. Alarmingly, more caregivers $(42.7$ vs. $34.3 \%, P<0.05)$ in the ward group believed fever could lead to death or/and deafness (17.4 vs. $10.5 \%, P<0.05$ ) and even $0.6 \%$ caregivers in the ward group chose aspirin when the children had fever.

Conclusion: 'Fever phobia' also exists in Chinese caregivers. Fever related knowledge propaganda after admitted to hospital did not work effectively to improve the caregivers' understanding and management of fever and an effective way to alleviate 'Fever phobia'.

Keywords: Fever, Fever phobia, Caregivers, Ward, Outpatient, Knowledge

\footnotetext{
* Correspondence: sssxooo@sina.com

First author: Lili DongSubmitting author: Lili Dong

'Department of Pediatric, Second Affiliated Hospital of Wenzhou Medical University, 109 Xueyuan Road, Wenzhou, Zhejiang Province 325027, China Full list of author information is available at the end of the article
} 


\section{Background}

Fever is very common in children, usually indicating an underlying viral infection which is often harmless and self-limiting, while fever is sometimes a response to severe bacterial infection requiring timely and appropriate medical intervention [1], and always leading to a frequent concern for parents and caregivers [2,3]. Parents and caregivers often misinterpret fever as being dreadful and harmful to their children, and believed that fever could cause brain damage or even death [4-6]. Fear of fever may sometimes results in frequent visits to the emergency department or clinic unnecessarily, thus leading to unscheduled physician visits, inappropriate treatments and unexpected financial budget [7]. Such misconception about fever has been coined as "fever phobia" by Schmitt in 1980 [4]. Since Schmitt's study of "fever phobia" in caregivers, similar studies have been conducted in many other countries to describe the unrealistic fears about fever in both caregivers and healthcare professionals $[8,9]$. Though more than 20 years has passed after the initial study, fever phobia still exists in the United States as well as in the other countries [10-16].

The wide existence of 'Fever phobia' reveals that the majority of caregivers think fever is harmful to their children and regard it as a disease rather than a symptom or sign of illness [4, 17-19], which explains the fear of fever and further intensifies the popularity of 'Fever phobia'. In China, we found that some caregivers even administer antipyretics without doctors' advice and ask pediatricians for antibiotic infusion for the purpose of rapid reduction of temperature, reflecting that 'Fever phobia' also exists in China and it may be more severe among caregivers. Besides, physical cooling methods are also included, such as undressed, tepid sponging, cold sponging, cold toweling, alcohol sponging or wine sponging. Actually, fever is a natural adaptive process which may improve the body's resistance to future infections and the frequent use of antipyretics to artificially reduce the body temperature may inhibit this process [20]. Moreover, in children with febrile illness, no evidence has been found that the height of temperature correlates with the severity of illness except for that in very young children [21] and no evidence suggests that fever reducing improves morbidity or mortality [22]. Studies have shown that physical methods of temperature reduction do not treat the cause of fever and may cause discomfort, shivering, resulting in vasoconstriction and an increase in temperature and metabolism [23-25], caregivers still ignorantly apply them.

According to previous studies, education in the waiting place could help caregivers know well about fever and deal with it appropriately [26-29]. To the best of our knowledge, although many reports related to 'Fever phobia' have been conducted, no studies about the difference between the outpatient department (OPD) group and the ward group have been conducted. Among most hospitals in China, education by doctors or nurses about related diseases takes place after admission in the hospital.

Our objectives for this study is to explore caregivers' attitudes towards fever and compare the attitudes between the OPD group and the ward group, and to determine whether the caregivers feel relieved and whether the education works after admitted to hospital.

\section{Methods \\ Design}

A cross-sectional survey was conducted as face-to-face interview between June 2012 and Feb 2013 in Wenzhou, China, which is a city that lies in the middle of east coast of China, southeast of Zhejiang province, and it is the economic, cultural and transportation center of Zhejiang. We selected a convenience sample of patients who were available and consented to be in the study while waiting at the OPD, and those with caregivers in the wards. All the respondents in the ward group had been educated for fever-related knowledge when interviewed. Children less than 3 months old and caregivers with experience of working in healthcare institutions and those who had the experience of hospitalization were excluded. According to Chinese Tradition, the questionnaire was re-administrated after Schmitt', and was validated using content validity by an expert panel that comprised a senior clinical pediatrician, a senior clinical nurse and clinical educators. It consists of demographic information (e.g. patients' age, place of residence) and 18 questions including caregivers' knowledge about fever, causes of fever, possible effects of fever, concerns about fever, fever management, and source of information about fever. Additional information was collected from caregivers in the ward as to whether caregivers felt relieved, and received education from doctors and nurses after admitted to hospital. Caregivers gave verbal and written consent. The Second Hospital of Wenzhou Medical University Research Ethics Committee approved the study.

\section{Statistical analysis}

Data analysis was performed with SPSS 19.0 for Windows. Student's $t$ test was used for continuous variables; $X^{2}$ analysis was used for dichotomous variables. If the $p$ value was $<0.05$, it was considered significant.

\section{Results}

\section{Demographics}

Of all the 621 caregivers, 316 (51\%) from the ward and 305 (49 \%) from the OPD agreed to be in the survey and 
were interviewed. The ward group and the OPD group differed demographically by both 'caregiver's occupation' and 'place of residence' (Table 1). Regarding to caregiver's occupation, in the ward group, $33.9 \%$ were house wives or had no job, $32.0 \%$ self-employed, $14.2 \%$ workmen, $10.4 \%$ institutional organization workers and $8.2 \%$ worked for enterprise, while in the OPD, the most were workmen, accounting for $34.2 \%$, followed by $27.8 \%$ caregivers who had no job, $19.9 \%$ self-employed, $10.3 \%$ working for enterprise and $6.4 \%$ institutional

Table 1 Distribution of demographic characteristics

\begin{tabular}{|c|c|c|c|c|}
\hline \multirow[t]{2}{*}{ Variables } & \multirow{2}{*}{$\begin{array}{l}\text { Total } \\
n=621(\%)\end{array}$} & \multirow{2}{*}{$\begin{array}{l}\text { OPD } \\
n=305(\%)\end{array}$} & \multirow{2}{*}{$\begin{array}{l}\text { Ward } \\
n=316(\%)\end{array}$} & \multirow[t]{2}{*}{$p$ value } \\
\hline & & & & \\
\hline \multicolumn{5}{|l|}{ Caregivers } \\
\hline Mothers & $472(76.0)$ & $221(72.5)$ & $251(79.4)$ & \\
\hline Fathers & $126(20.3)$ & $73(23.9)$ & $53(16.8)$ & \\
\hline Grandparents & $21(3.4)$ & $11(3.6)$ & $12(3.8)$ & 0.085 \\
\hline \multicolumn{5}{|l|}{ Caregiver's age, years } \\
\hline 25 or younger & $88(14.2)$ & $49(16.1)$ & $39(12.3)$ & \\
\hline $26-35$ & $414(66.7)$ & $193(63.3)$ & $221(69.9)$ & \\
\hline $36-45$ & $103(16.6)$ & $57(18.7)$ & $46(14.6)$ & \\
\hline 46 or older & $16(2.6)$ & $6(2.0)$ & $10(3.2)$ & 0.171 \\
\hline \multicolumn{5}{|l|}{ Caregiver's occupation } \\
\hline Unemployed (House wife) & $191(30.8)$ & $84(27.8)$ & $107(33.9)$ & \\
\hline Workman & $149(24.0)$ & $104(34.2)$ & $45(14.2)$ & \\
\hline Self-employed & $162(26.1)$ & $61(19.9)$ & $101(32.0)$ & \\
\hline Enterprise & $58(9.3)$ & $32(10.3)$ & $26(8.2)$ & \\
\hline Institutional organization workers & $53(20.3)$ & $20(6.4)$ & $33(10.4)$ & \\
\hline Government officer & $8(1.3)$ & $4(1.4)$ & $4(1.3)$ & $<0.001$ \\
\hline \multicolumn{5}{|l|}{ Educational level } \\
\hline Illiterate & $9(1.4)$ & $3(1.1)$ & $6(1.9)$ & \\
\hline Primary school & $66(10.6)$ & $28(9.8)$ & $38(12.0)$ & \\
\hline Middle school & $228(36.7)$ & $120(42.1)$ & $108(34.2)$ & \\
\hline High school & $139(22.4)$ & $56(19.6)$ & $83(26.3)$ & \\
\hline College & $159(25.6)$ & $78(27.4)$ & $81(25.6)$ & 0.143 \\
\hline \multicolumn{5}{|l|}{ Native place } \\
\hline Wenzhou, Zhejiang & $501(80.7)$ & $249(81.6)$ & $252(79.7)$ & \\
\hline Non Wenzhou & $120(19.3)$ & $56(18.4)$ & $64(20.3)$ & 0.550 \\
\hline \multicolumn{5}{|l|}{ Place of residence } \\
\hline Countryside & $367(59.1)$ & $180(59.2)$ & $187(59.2)$ & \\
\hline County town & $101(16.3)$ & $40(13.0)$ & $61(19.3)$ & \\
\hline City & $153(24.6)$ & $85(27.8)$ & $68(21.5)$ & 0.045 \\
\hline \multicolumn{5}{|l|}{ Number of children } \\
\hline 1 & $342(55.1)$ & $178(58.4)$ & $164(51.9)$ & \\
\hline 2 & $241(38.8)$ & $112(36.7)$ & $129(40.8)$ & \\
\hline 3 or more & $38(6.1)$ & $15(4.9)$ & $23(7.3)$ & 0.196 \\
\hline \multicolumn{5}{|l|}{ Annual income of the family } \\
\hline$\$ 5000$ or less & $144(23.2)$ & $65(21.4)$ & $79(24.9)$ & \\
\hline$\$ 5000-8000$ & $204(32.9)$ & $107(35.0)$ & $97(30.7)$ & \\
\hline$\$ 8000-16,000$ & $167(26.9)$ & $80(26.3)$ & 87 (27.6) & \\
\hline$\$ 16,000$ or more & $106(17.1)$ & $53(17.3)$ & $53(16.9)$ & 0.583 \\
\hline
\end{tabular}


organization workers, separately $(p<0.05)$. Caregivers living in countryside accounted for $59.2 \%$ in both of the two groups, while $21.5 \%$ from the ward group lived in the city and those who lived in the city from the OPD group accounted for $27.8 \%(p<0.05)$. The remaining demographic variables were comparable between groups. Mothers accounted for $76.0 \%$ of those interviewed, and $66.7 \%$ of those interviewed were between the ages 26 and 35. Among those interviewed, $36.7 \%$ graduated from middle school, $25.6 \%$ from college, $22.4 \%$ from high school, $10.6 \%$ from primary school and $1.4 \%$ received no education. Most of those interviewed (80.7\%) were local residents, and $55.1 \%$ of the caregivers interviewed had only one child, $38.8 \%$ had 2 , while $6.1 \%$ had three or more. At the time of interview, the family annual income was $\$ 5000$ or less (23.2 \%), \$5000-8000 (32.9\%), \$8000-16,000 (26.9\%) or $\$ 16,000$ or more (17.1\%). (All the data above were shown in Table 1).

\section{Definition of fever and high fever}

When asked about the definition of fever, $9.8 \%$ caregivers (10.2 vs. $9.5 \%$ ) considered $37{ }^{\circ} \mathrm{C}$ as the threshold of fever, $39.8 \%$ considered $37.5{ }^{\circ} \mathrm{C}$, and a large number of caregivers considered $38{ }^{\circ} \mathrm{C}$. Except one in the ward group who did not know, the rest defined the temperature below $38{ }^{\circ} \mathrm{C}$ as fever. Moreover, the most common high fever threshold was $39{ }^{\circ} \mathrm{C}$, respectively reported by $55.4 \%$ and $57.3 \%$ caregivers, then, followed by $38.5{ }^{\circ} \mathrm{C}$ (26.6 vs. $27.8 \%$ ) and $40{ }^{\circ} \mathrm{C}$ (6.2 vs. $8.9 \%$ ). While the two groups did not differ statistically on the definition of fever and high fever, and data was specifically illustrated in Table 2 .

Table 2 Definition of fever and high fever by caregivers

\begin{tabular}{lcccc}
\hline Variables & Total & OPD & Ward & $p$ value \\
& $n=621(\%)$ & $n=305(\%)$ & $n=316(\%)$ & \\
\hline \multicolumn{5}{l}{ Body temperature considered as fever $\left({ }^{\circ} \mathrm{C}\right)$} \\
$\geq 37$ & $61(9.8)$ & $31(10.2)$ & $30(9.5)$ & \\
$\geq 37.5$ & $247(39.8)$ & $118(38.7)$ & $129(40.8)$ & \\
$\geq 38$ & $312(50.2)$ & $156(51.1)$ & $156(49.4)$ & \\
Unknown & $1(0.2)$ & $0(0.0)$ & $1(0.3)$ & 0.726 \\
Body temperature considered as high fever $\left({ }^{\circ} \mathrm{C}\right)$ & & \\
$\geq 37$ & $1(0.2)$ & $1(0.3)$ & $0(0.0)$ & \\
$\geq 38$ & $53(8.5)$ & $35(11.5)$ & $18(5.7)$ & \\
$\geq 38.5$ & $169(27.2)$ & $81(26.6)$ & $88(27.8)$ & \\
$\geq 39$ & $350(56.4)$ & $169(55.4)$ & $181(57.3)$ & \\
$\geq 40$ & $47(7.6)$ & $19(6.2)$ & $28(8.9)$ & \\
Unknown & $1(0.2)$ & $0(0.0)$ & $1(0.3)$ & 0.085 \\
\hline
\end{tabular}

\section{Knowledge about fever}

With respect to the knowledge about fever, about $2.8 \%$ caregivers in the ward group would give antipyretics at the temperature of $37{ }^{\circ} \mathrm{C}, 39.6 \%$ at the temperature of $38{ }^{\circ} \mathrm{C}, 47.2 \%$ at the temperature of $38.5{ }^{\circ} \mathrm{C}, 10.4 \%$ at the temperature of $39{ }^{\circ} \mathrm{C}$; While in the OPD, the percentage of caregivers administrating antipyretics at each temperature above were 6.6, 40.3, 44.9, $7.2 \%$, respectively. Moreover, three caregivers in this group had even no idea. It was of statistical significance between the two groups.

The most common antipyretics chosen by caregivers were ibuprofen, and the proportion in the ward group and the outpatient group were 78.2 and $80.7 \%$ separately. The percentage of caregivers $(9.5 \%)$ who would use acetaminophen were the same between the two groups. And the method of combining or alternating ibuprofen and acetaminophen was also seen in $4.7 \%$ caregivers in the ward group and $3.9 \%$ in the OPD group. While $2(0.6 \%)$ caregivers in the ward group chose aspirin. The left $7.0 \%$ in the ward group and $5.9 \%$ in the outpatient group had other choices, mostly were Chinese traditional medicine, such as Radix isatidis (banlangen), Qingkailing granules (qingkailingkeli), Taurine Granules and Radix Bupleuri Oral Liquids (Chaihukoufuye), and others included Compound Zinc Gluconate and Ibuprofen Granules and suppositories. And most of the caregivers, $63.0 \%$ in the outpatient group would awaken their febrile sleeping children for antipyretics administration, while those in the ward group were significantly more $(p<0.05)$ and the percentage was up to $72.8 \%$.

With regard to the way of getting antipyretics, $38.3 \%$ caregivers in the ward group and $29.2 \%$ in the outpatient group went to drugstores, but hospital was still the major choice, $56.3 \%$ in the ward group and $66.6 \%$ in the outpatient group, while $5.4 \%$ in the ward group and $4.3 \%$ in the outpatient group would go to both drugstore and hospital, as shown in Table 3 and there was statistical significance between the two groups $(p<0.05)$.

Even if there was not significant evidence showing any benefits of physical cooling, $47.8 \%$ in the ward group and $44.6 \%$ in the outpatient group, nearly half of the caregivers still used tepid sponging for their feverish children and there were significantly more caregivers choosing cold sponging ( 0.6 vs. $4.9 \%, p<0.05)$. While 2 caregivers even chose wine sponging. There were $34.2 \%$ caregivers in the ward group and $24.6 \%$ in the outpatient group choosing cold toweling, which was of statically significance $(p<0.05)$. In terms of those choosing alcohol sponging, the number was nearly the same, besides, there was the convenient method fever cooling patch preferred by $12.0 \%$ in the ward group and $8.9 \%$ in the outpatient group. Then there were $6.6 \%$ 
Table 3 Knowledge about fever

\begin{tabular}{|c|c|c|c|c|}
\hline \multirow[t]{2}{*}{ Variables } & Total & \multirow{2}{*}{$\begin{array}{l}\text { OPD } \\
n=305(\%)\end{array}$} & Ward & \multirow[t]{2}{*}{$p$ value } \\
\hline & $n=621(\%)$ & & $n=316(\%)$ & \\
\hline \multicolumn{5}{|c|}{ Body temperature considered to give antipyretics $\left({ }^{\circ} \mathrm{C}\right)$} \\
\hline$\geq 37$ & $29(4.7)$ & $20(6.6)$ & $9(2.8)$ & \\
\hline$\geq 38$ & $248(39.9)$ & $123(40.3)$ & $125(39.6)$ & \\
\hline$\geq 38.5$ & $286(46.1)$ & $137(44.9)$ & $149(47.2)$ & \\
\hline$\geq 39$ & $55(8.9)$ & $22(7.2)$ & $33(10.4)$ & \\
\hline Unknown & $3(0.5)$ & $3(1.0)$ & $0(0.0)$ & 0.046 \\
\hline \multicolumn{5}{|l|}{ Antipyretics used } \\
\hline Ibuprofen & $493(79.4)$ & $246(80.7)$ & $247(78.2)$ & \\
\hline Acetaminophen & $59(9.5)$ & $29(9.5)$ & $30(9.5)$ & \\
\hline Ibuprofen \&Acetaminophen & $27(4.3)$ & $12(3.9)$ & $15(4.7)$ & \\
\hline Aspirin & $2(0.3)$ & $0(0.0)$ & $2(0.6)$ & \\
\hline Banlangen $^{a}$ & $1(0.2)$ & $0(0.0)$ & $1(0.3)$ & \\
\hline Qingkailingkelib & $3(0.5)$ & $1(0.2)$ & $2(0.6)$ & \\
\hline Chaihukoufuye $^{c}$ & $2(0.3)$ & $1(0.2)$ & $1(0.3)$ & \\
\hline Compound Xinbu Granules ${ }^{d}$ & $3(0.5)$ & $1(0.2)$ & $2(0.6)$ & \\
\hline Niuhuangsuankeli ${ }^{e}$ & $3(0.5)$ & $1(0.2)$ & $2(0.6)$ & \\
\hline Xiaoerqingrejiekeli $^{f}$ & $3(0.5)$ & $1(0.2)$ & $2(0.6)$ & \\
\hline Unknown & $25(4.0)$ & $13(4.3)$ & $12(3.8)$ & 0.634 \\
\hline \multicolumn{5}{|l|}{ Giving antipyretics during sleep } \\
\hline Yes & $422(68.0)$ & $192(63.0)$ & $230(72.8)$ & \\
\hline No & $199(32.0)$ & $113(37.0)$ & $86(27.2)$ & 0.009 \\
\hline \multicolumn{5}{|l|}{ Where to get antipyretics } \\
\hline Drugstore & $210(33.8)$ & $89(29.2)$ & $121(38.3)$ & \\
\hline Hospital & $381(61.4)$ & $203(66.6)$ & $178(56.3)$ & \\
\hline Drugstore \& Hospital & $30(4.8)$ & $13(4.3)$ & $17(5.4)$ & 0.032 \\
\hline \multicolumn{5}{|l|}{ The method of physical cooling } \\
\hline Tepid sponging & $287(46.2)$ & $136(44.6)$ & $151(47.8)$ & 0.469 \\
\hline Cold sponging & $17(2.7)$ & $15(4.9)$ & $2(0.6)$ & 0.001 \\
\hline Cold toweling & $93(15.0)$ & 75 (24.6) & $108(34.2)$ & 0.01 \\
\hline Alcohol sponging & $121(19.5)$ & $58(19.0)$ & $63(19.9)$ & 0.803 \\
\hline Fever cooling patch & $65(10.5)$ & $27(8.9)$ & $38(12.0)$ & 0.197 \\
\hline Unknown/No & $47(7.6)$ & $26(8.5)$ & $21(6.6)$ & 0.376 \\
\hline Wine & $2(0.3)$ & $0(0.0)$ & $2(0.6)$ & 0.499 \\
\hline
\end{tabular}

${ }^{a}$ Radix isatidis; ${ }^{b}$ Qingkailing granules; ${ }^{\mathrm{C}}$ Taurine Granules and Radix Bupleuri Oral Liquids; ${ }^{\mathrm{d}}$ Compound Zinc Gluconate and Ibuprofen Granules; ${ }^{\mathrm{e}}$ Taurine Granules; ${ }^{\mathrm{f}}$ Qingrejie granules

caregivers in the ward group and $8.5 \%$ in the outpatient group who had never used the methods of physical cooling or had no idea (shown in Table 3).

\section{Potential effects of fever}

The most potential effects of fever predicted by caregivers was brain damage, which was up to $74.7 \%$, although there was no statistical significance between the two groups ( 75.1 vs. $74.4 \%, p>0.05)$. There were significantly more caregivers in the ward predicting that death was the second most possible complication of fever (34.4 vs. $42.7 \%, p<0.05$ ). According to the data obtained, $21.9 \%$ caregivers believed fever can cause convulsion though without difference between the two groups ( 22.6 vs. $21.2 \%, p>0.05$ ). As for the loss of hearing, the percentage was obviously higher in the ward group and it was statistically significant (10.5 vs. $17.4 \%$, $p<0.05)$. In addition, $11.9 \%$ caregivers (10.2 vs. $13.6 \%)$ regarded blindness as another possible danger of fever, while a small number of caregivers (1.7 vs. $1.9 \%)$ stated 
they "Have no idea" at all. Data were displayed in detail in Table 4.

\section{How often temperature checked and level of caregiver's worrisome}

A vast majority of caregivers took their febrile child's temperature at least every $2 \mathrm{~h}$ or more frequently, $32.7 \%$ checked temperature every 1 to $2 \mathrm{~h}, 33.3 \%$ checked every $30 \mathrm{~min}$ to $1 \mathrm{~h}, 11.8 \%$ did it every 15 to $30 \mathrm{~min}$. While $1.0 \%$ checked the temperature every less than $15 \mathrm{~min}$, only $20.6 \%$ checked more than $2 \mathrm{~h}$. All the data obtained about frequency of checking temperature between two groups was of no statistical significance $(p>0.05)$. Among 621 caregivers surveyed, 7 caregivers stated they were not worried at all, while $44.4 \%$ were very worried and $34.3 \%$ were extremely worried. Again, they did not differ statistically $(p>0.05)$, as shown in Table 5 .

\section{Sources for information about fever}

Doctors and nurses were considered to be the primary source for information about fever, and the percentage was significantly higher in the ward group than that in the OPD group (53.3 vs. $43.0 \%, p<0.05$ ). Compared with the OPD group, more caregivers chose Internet as their source for information about fever in the ward group. As to the experience, the proportion is statically higher in the ward group than that in the OPD group. While there was no difference between the two groups about the other sources for information of fever, such as TV or newspapers, professional lectures and neighbors or relatives, seen in Table 6.

\section{Discussion}

Fever is defined as 'an elevation of body temperature above the normal daily variation, usually take the body temperature $38{ }^{\circ} \mathrm{C}$ or higher as a criteria. It's the most common reason that caregivers took their children to doctors, accounting for almost one third of all the causes for children seeking medical advice [30-32]. However, the majority caregivers thought fever harmful to their children and considered it as a disease rather

Table 4 Potential effects of fever

\begin{tabular}{lcccc}
\hline Variables & Total & OPD & Ward & $p$ value \\
& $n=621(\%)$ & $n=305(\%)$ & $n=316(\%)$ & \\
\hline Brain damage & $464(74.7)$ & $229(75.1)$ & $235(74.4)$ & 0.838 \\
Death & $240(38.6)$ & $105(34.4)$ & $135(42.7)$ & 0.034 \\
Convulsion & $136(21.9)$ & $69(22.6)$ & $67(21.2)$ & 0.669 \\
Deafness & $87(14.0)$ & $32(10.5)$ & $55(17.4)$ & 0.020 \\
Blindness & $74(11.9)$ & $31(10.2)$ & $43(13.6)$ & 0.185 \\
Have no idea & $11(1.8)$ & $5(1.7)$ & $6(1.9)$ & 0.806 \\
\hline
\end{tabular}

Table 5 How often temperature checked and level of caregiver's worrisome

\begin{tabular}{|c|c|c|c|c|}
\hline \multirow[t]{2}{*}{ Variables } & Total & \multirow{2}{*}{$\begin{array}{l}\text { OPD } \\
n=305(\%)\end{array}$} & Ward & \multirow[t]{2}{*}{$p$ value } \\
\hline & $n=621(\%)$ & & $n=316(\%)$ & \\
\hline \multicolumn{5}{|c|}{ How often temperature checked } \\
\hline$\leq 15 \min$ & $6(1.0)$ & $5(1.6)$ & $1(0.3)$ & \\
\hline 15-30 min & $73(11.8)$ & $38(12.5)$ & $35(11.1)$ & \\
\hline $30 \mathrm{~min}-1 \mathrm{~h}$ & $207(33.3)$ & $98(32.1)$ & $109(34.5)$ & \\
\hline $1 \mathrm{~h}-2 \mathrm{~h}$ & $203(32.7)$ & $99(32.5)$ & $104(32.9)$ & \\
\hline$\geq 2 \mathrm{~h}$ & $128(20.6)$ & $63(20.7)$ & $65(20.6)$ & \\
\hline Unknown & $4(0.6)$ & $2(0.7)$ & $2(0.6)$ & 0.648 \\
\hline \multicolumn{5}{|c|}{ Level of caregiver's worrisome } \\
\hline Not worried at all & $7(1.1)$ & $2(0.7)$ & $5(1.6)$ & \\
\hline A little worried & $125(20.1)$ & $71(23.3)$ & $54(17.1)$ & \\
\hline Very worried & $276(44.4)$ & $137(44.9)$ & $139(44.0)$ & \\
\hline Extremely worried & $213(34.3)$ & $95(31.1)$ & $118(37.3)$ & 0.116 \\
\hline
\end{tabular}

than a symptom or a sign of illness and necessary to be treated, thus leading to parents waking up their children to give antipyretics, in the pursuit of reducing to normal temperature and unimaginable and unrealistic worrisome about fever, namely 'Fever phobia' [4, 9, 33-36].

In our study, $9.8 \%$ caregivers considered $37{ }^{\circ} \mathrm{C}$ as the threshold of fever, $39.8 \%$ considered $37.5{ }^{\circ} \mathrm{C}$, and the rest $50.2 \%$ of caregivers considered $38{ }^{\circ} \mathrm{C}$ in the OPD. Except one in the ward group who did not know, the rest defined the temperature below $38{ }^{\circ} \mathrm{C}$ as fever. And the most common high fever threshold was $39{ }^{\circ} \mathrm{C}$, reported by 55.4 and $57.3 \%$ caregivers, respectively, then followed by $38.5{ }^{\circ} \mathrm{C}$. But the less common high fever threshold was $40{ }^{\circ} \mathrm{C}$. Other studies have reported similar findings. In Chang's study, $81 \%$ of participants considered temperature below $38{ }^{\circ} \mathrm{C}$ as the threshold of fever and $69.6 \%$ considered a temperature below $39{ }^{\circ} \mathrm{C}$ as the threshold of high fever [37]. In Karwowska's study, parents considered a temperature $37.9{ }^{\circ} \mathrm{C}$ as the threshold of fever and $39.1^{\circ} \mathrm{C}$ as high fever [13]. In Poirier's study, $55 \%$ parents considered a temperature below $37.8{ }^{\circ} \mathrm{C}$ as

Table 6 Sources for information about fever

\begin{tabular}{lcclr}
\hline Variables & Total & OPD & Ward & $p$ value \\
& $n=621(\%)$ & $n=305(\%)$ & $n=316(\%)$ & \\
\hline TV or newspaper & $153(24.6)$ & $84(27.5)$ & $69(21.8)$ & 0.099 \\
Parent's books & $179(28.8)$ & $87(28.5)$ & $92(29.1)$ & 0.871 \\
Internet & $139(22.4)$ & $58(19.0)$ & $81(25.6)$ & 0.048 \\
Professional lectures & $28(4.5)$ & $13(4.1)$ & $15(4.7)$ & 0.771 \\
Neighbors or relatives & $126(20.3)$ & $68(22.3)$ & $58(18.4)$ & 0.222 \\
Doctors and nurses & $300(48.3)$ & $131(43.0)$ & $169(53.5)$ & 0.009 \\
Experience & $155(25.0)$ & $45(14.8)$ & $110(34.8)$ & $<0.001$ \\
\hline
\end{tabular}


the threshold of fever and $17.5 \%$ as a temperature below $38.9{ }^{\circ} \mathrm{C}$ as high fever [38]. After admitted to hospital, though 83.9 \% caregivers stated to have received education about fever and $96.5 \%$ said to feel relieved, between the two groups, there was no significant difference as to the definition of fever and high fever at all, moreover, no difference was found about the antipyretics used between the two groups as well. It seemed that caregivers in China mainland had the same level of misunderstanding about the definition of fever as caregivers from other countries and the education after admission to hospital did not work effectively indicating that the education might did not refer to the related knowledge, or the education was not accepted, or even the related knowledge was rightly educated.

Among previously reported studies, $56 \%$ parents were very worried about the possible harm caused by childhood fever in United States [34], 50-60 \% in a Singaporean research [39], $65 \%$ in a UK one [15], and $86.8 \%$ parents in Taiwan stated to be worried [37]. In the present study, we found that $44.4 \%$ caregivers were very worried and $34.3 \%$ were even more worried. And $57.2 \%$ would take their febrile children to hospitals at night, $74.7 \%$ thought fever could cause brain damage, $4.7 \%$ would give antipyretics when the temperature was higher than $37{ }^{\circ} \mathrm{C}$ and $38.0 \%$ would choose $38{ }^{\circ} \mathrm{C}$ as threshold for antipyretics, $68.0 \%$ would wake up their sleeping children for antipyretics, indicating a deep misunderstanding and unrealistic worrisome of fever, which was consistent with previous studies [9, 34, 40]. Such misunderstanding and worrisome of fever resulted in inappropriate or unnecessary treatments, thus leading to unexpected harm to children. Besides, there were no significant differences between the two groups in the above items, except that more caregivers in the ward group would wake up their sleeping children for antipyretics and thought deafness was one of the most potential effects of fever, suggesting the reason why the caregivers receiving inpatient care could be more concerned is the possibility of their child's more severe disease. Moreover, those caregivers in the ward group might think that the fever would persist or get worse and could lead to more serious damage to children, which also reflected that the education after admission to the hospital did not work.

In previous studies, many kinds of harmfulness thought by caregivers were related to fever, the most common were convulsion, brain damage $[4,34,39]$ and even death [4-6]. Crocetti et al. found that $53 \%$ caregivers thought fever would rise if left untreated and $58 \%$ thought fever itself could lead to brain damage or even death [34]. While in our study, in the outpatient group, $75.1 \%$ thought fever could lead to brain damage, $34.4 \%$ thought it could lead to death, $22.6 \%$ thought it could lead to convulsion, $10.5 \%$ thought it could lead to deafness and $10.2 \%$ thought it was blindness, while in the ward group, the percentage was $74.4,42.7,21.2,17.4,13.6 \%$ respectively, consistent with the previous study, Enarson et al. found $74 \%$ parents thought fever dangerous and $90.3 \%$ tried to reduce temperature [35]. The first three potential effects of fever predicated by caregivers were brain damage, death and convulsion, which may be the major reason why caregivers felt so worried about the fever and were in the pursuit of reducing to normal temperature. In fact, fever in children were mostly caused by virus [21, 41, 42], and if the children were with normal spirits and had sufficient water without dehydration, it would disappear without treatment.

Moreover, there are a number of physical cooling methods used to reduce body temperature, including undressing, sponging or toweling with tepid or cold water or alcohol, and these are involved in convection and evaporation but do not treat the underlying causes of the fever and the physical methods can cause discomfort [43, 44], such as shivering, hypoglycemia, coma and even death [4]. In our survey, though more caregivers in the ward group chose cold toweling and less chose cold sponging, there were equivalent caregivers in two groups choosing tepid sponging, alcohol sponging, fever cooling patch, and far more less caregiving did not know what physical cooling methods or did not put that into use, indicating that the education by doctors and nurses after admitted to hospital did not work as no physical interventions for reducing temperature were recommended in the recent published guideline for feverish illness for children [20].

Our findings underline the existing of 'Fever phobia' in Wenzhou, China but not the value of education after admission to a hospital in order to modify the caregivers' understanding and management of fever. Caregivers took doctors and nurses as the first choice of source of information about fever, while there was no statistical significance between the two groups in most items, indicating that the education might not work effectively. Though previous education [45-47] showed positive effects, here it did not show fever-related education an effective action to improve the caregivers' understanding and management of fever and an effective way to alleviate 'Fever phobia'. Thus there are yet a lot that we can do to it.

\section{Limitations}

The findings of this study should be considered within the following limitations. The study was undertaken at one pediatric hospital and the sample was small thereby limiting the generalisability of other findings and probably not being able to totally represent the national data. The caregivers interviewed had no experience of hospitalization, limiting the findings of the understanding of fever in those 
with the experience of hospitalization. We also care about the external validity of our findings relating to the perceptions of doctors and nurses. Although the doctors and nurses involved in the ward group survey have a variety of training backgrounds, knowledge base and perspective may differ when educating caregivers. Besides, there is also the possibility that caregivers in ward group might be more concerned due to their child's more severe disease. Here, the reasons for outpatient visits and hospitalization were not studied and analyzed, which we will do during the next related study.

\section{Conclusions}

"Fever phobia" is still widespread among caregivers and the vast majority believes that fever is harmful and it also exists in Chinese caregivers. In our study, it did not show fever education an effective action to improve the caregivers' understanding and management of fever and an effective way to alleviate 'Fever phobia'. Considering that there was no statistical significance between the two groups in some items, and both caregivers in the ward group and in the OPD group, doctors and nurses were considered as the primary source of information, underlying possible problems with the education, which suggested the importance to guarantee that doctors and nurses give parents correct and consistent information in order to eliminate "fever phobia", some related training might be necessary.

\section{Competing interests}

The authors declare that they have no competing interests.

\section{Authors' contributions}

XS was principal investigator of the study. She participated in the design of the study, development of the questionnaire and drafting of the manuscript. LD participated in the development of the questionnaire, data collection and data analysis and took the lead on drafting the manuscript. JJ participated in the development of the questionnaire, the data collection and data analysis. $L L$ and $\sqcup$ participated in data collection, statistical analysis and the interpretation of results and in the drafting of the manuscript. All authors read and approved the final manuscript.

\section{Acknowledgements}

The authors thank the caregivers who took part in the interviews.

\section{Author details \\ 'Department of Pediatric, Second Affiliated Hospital of Wenzhou Medical University, 109 Xueyuan Road, Wenzhou, Zhejiang Province 325027, China. ${ }^{2}$ Children's hospital of Zhengzhou, Zhengzhou, Henan Province 450018, China.}

Received: 24 July 2014 Accepted: 5 October 2015

Published online: 19 October 2015

\section{References}

1. Finkelstein JA, Christiansen $C L$, Platt R. Fever in pediatric primary care: occurrence, management, and outcomes. Pediatrics. 2000;105(Supplement 2):260-6.

2. Baker MD, Monroe KW, King WD, Sorrentino A, Glaeser PW. Effectiveness of fever education in a pediatric emergency department. Pediatr Emerg Care. 2009;25(9):565-8.
3. Dawood OT, Ibrahim MI, Palaian S. Parent's knowledge and management of their children's ailments in Malaysia. Pharm Pract (Internet). 2010;8(2):96-102.

4. Schmitt BD. Fever phobia: misconceptions of parents about fevers. Am J Dis Child. 1980;134(2):176-81.

5. Walsh A, Edwards H. Management of childhood fever by parents: literature review. J Adv Nurs. 2006;54(2):217-27.

6. Chiappini E, Parretti A, Becherucci P, Pierattelli M, Bonsignori F, Galli L, et al. Parental and medical knowledge and management of fever in Italian pre-school children. BMC Pediatr. 2012;12(1):97.

7. Wallenstein MB, Schroeder AR, Hole MK, Ryan C, Fijalkowski N, Alvarez E, et al. Fever literacy and fever phobia. Clin Pediatr. 2013;52(3):254-9.

8. Abdullah M, Ashong E, Al Habib S, Karrar Z, Al Jishi N. Fever in children: diagnosis and management by nurses, medical students, doctors and parents. Ann Trop Paediatr. 1987;7(3):194-9.

9. Sarrell M, Cohen HA, Kahan E. Physicians', nurses', and parents' attitudes to and knowledge about fever in early childhood. Patient Educ Couns. 2002;46(1):61-5.

10. Andersen AR. Parental perception and management of school-age children's fevers. Nurse Pract. 1988;13(5):8-22.

11. Betz MG, Grunfeld AF. 'Fever phobia'in the emergency department: a survey of children's caregivers. Eur J Emerg Med. 2006;13(3):129-33.

12. Eskerud JR, Hoftvedt BO, Laerum E. Fever: knowledge, perception and attitudes. Results from a Norwegian population study. Fam Pract. 1991;8(1):32-6.

13. Karwowska A, Nijssen-Jordan C, Johnson D, Davies HD. Parental and health care provider understanding of childhood fever: a Canadian perspective. CJEM. 2002;4(6):394-400.

14. Kramer MS, Naimark L, Leduc DG. Parental fever phobia and its correlates. Pediatrics. 1985;75(6):1110-3

15. Purssell E. Parental fever phobia and its evolutionary correlates. J Clin Nurs. 2009;18(2):210-8.

16. Tessler H, Gorodischer R, Press J, Bilenko N. Unrealistic concerns about fever in children: the influence of cultural-ethnic and sociodemographic factors. Isr Med Assoc J. 2008;10(5):346.

17. Kohl KS, Marcy SM, Blum M, Jones MC, Dagan R, Hansen J, et al. Fever after immunization: current concepts and improved future scientific understanding. Clin Infect Dis. 2004:39(3):389-94.

18. El-Radhi ASM. Why is the evidence not affecting the practice of fever management? Arch Dis Child. 2008;93(11):918-20.

19. Nizet V, Vinci RJ, Lovejoy FH. Fever in children. Pediatr Rev. 1994;15(4):127-35.

20. Davis T. NICE guideline: feverish illness in children-assessment and initial management in children younger than 5 years. Archives of disease in childhood-Education \& practice edition 2013:edpract-2013-304792.

21. Richardson M, Lakhanpaul M. Assessment and initial management of feverish illness in children younger than 5 years: summary of NICE guidance. BMJ. 2007:334(7604):1163-4.

22. Sullivan JE, Farrar HC. Fever and antipyretic use in children. Pediatrics. 2011;127(3):580-7.

23. Meremikwu MM, Oyo-Ita A. Paracetamol versus placebo or physical methods for treating fever in children. Cochrane Database Syst Rev. 2002;2.

24. Newman J. Evaluation of sponging to reduce body temperature in febrile children. Can Med Assoc J. 1985:132(6):641.

25. Sharber $J$. The efficacy of tepid sponge bathing to reduce fever in young children. Am J Emerg Med. 1997;15(2):188-92.

26. Austin PE, Dunn KA, Kesler C, Brown CK. Discharge instructions: do illustrations help our patients understand them? Ann Emerg Med. 1995;25(3):317-20.

27. Corbett SW, White PD, Wittlake WA. Benefits of an informational videotape for emergency department patients. Am J Emerg Med. 2000;18(1):67-71.

28. Jolly BT, Scott JL, Sanford SM. Simplification of emergency department discharge instructions improves patient comprehension. Ann Emerg Med. 1995;26(4):443-6.

29. Kozak G, Yura H. A comparison of teaching methods for ED discharge instruction after head injury. J Emerg Nurs. 1988;15(1):18-22.

30. Massin M, Montesanti J, Gerard P, Lepage P. Spectrum and frequency of illness presenting to a pediatric emergency department. Acta Clin Belg. 2006;61(4):161-5.

31. Gorelick MH, Alpern ER, Alessandrini EA. A system for grouping presenting complaints: the pediatric emergency reason for visit clusters. Acad Emerg Med. 2005;12(8):723-31.

32. Villarreal SF, Berman S, Groothuis JR, Strange V, Schmitt BD. Telephone encounters in a university pediatric group practice a 2-year analysis of afterhour calls. Clin Pediatr. 1984;23(8):456-8. 
33. Taveras EM, Durousseau S, Flores G. Parents' beliefs and practices regarding childhood fever: a study of a multiethnic and socioeconomically diverse sample of parents. Pediatr Emerg Care. 2004;20(9):579-87.

34. Crocetti M, Moghbeli N, Serwint J. Fever phobia revisited: have parental misconceptions about fever changed in 20 years? Pediatrics. 2001;107(6):1241-6.

35. Enarson MC, Ali S, Vandermeer B, Wright RB, Klassen TP, Spiers JA. Beliefs and expectations of Canadian parents who bring febrile children for medical care. Pediatrics. 2012;130(4):e905-12.

36. Erkek N, Senel S, Sahin M, Ozgur O, Karacan C. Parents' perspectives to childhood fever: comparison of culturally diverse populations. J Paediatr Child Health. 2010;46(10):583-7.

37. Chang L-C, Liu C-C, Huang M-C. Parental knowledge, concerns, and management of childhood fever in Taiwan. J Nurs Res. 2013;21(4):252-60.

38. Poirier MP, Collins EP, McGuire E. Fever phobia: a survey of caregivers of children seen in a pediatric emergency department. Clin Pediatr. 2010;49(6):530-4.

39. Soon W, Cheong S, Hong C. Fever phobia in a primary healthcare setting: a Singapore perspective. Ann Acad Med Singap. 2003;32(5 Suppl):S26-7.

40. Arica SG, Arica V, Onur H, Gülbayzar S, Dağ H, Obut Ö. Knowledge, attitude and response of mothers about fever in their children. Emerg Med J. 2012;29(12):e4-4.

41. Smitherman HF, Caviness AC, Macias CG. Retrospective review of serious bacterial infections in infants who are 0 to 36 months of age and have influenza A infection. Pediatrics. 2005;115(3):710-8.

42. Purcell K, Fergie J. Concurrent serious bacterial infections in 912 infants and children hospitalized for treatment of respiratory syncytial virus lower respiratory tract infection. Pediatr Infect Dis J. 2004;23(3):267-9.

43. Meremikwu M, Oyo-Ita A. Physical methods for treating fever in children. Cochrane Database Syst Rev. 2003;(2):Cd004264.

44. Lenhardt R, Negishi C, Sessler DI, Vuong K, Bastanmehr H, Kim JS, et al. The effects of physical treatment on induced fever in humans. Am J Med. 1999;106(5):550-5.

45. Considine J, Brennan D. Emergency nurses' opinions regarding paediatric fever: the effect of an evidence-based education program. Australas Emerg Nurs J. 2006;9(3):101-11.

46. Considine J, Brennan D. Effect of an evidence-based education programme on ED discharge advice for febrile children. J Clin Nurs. 2007;16(9):1687-94.

47. Baker MD, Monroe KW, King WD, Sorrentino A, Glaeser PW. Effectiveness of fever education in a pediatric emergency department. Pediatr Emerg Care. 2009;25(9):565-8.

\section{Submit your next manuscript to BioMed Central and take full advantage of:}

- Convenient online submission

- Thorough peer review

- No space constraints or color figure charges

- Immediate publication on acceptance

- Inclusion in PubMed, CAS, Scopus and Google Scholar

- Research which is freely available for redistribution 